\title{
The Moral Value of Yorùbá Moonlight Tales
}

\author{
Timothy Adeyemi Akanbi \\ Department of Linguistics and Nigerian Languages Ekiti State University, Ado-Ekiti, Nigeria \\ Email: yemiakanbi@gmail.com
}

Received 21 July 2014; revised 25 August 2014; accepted 3 September 2014

Copyright (C) 2014 by author and Scientific Research Publishing Inc.

This work is licensed under the Creative Commons Attribution International License (CC BY). http://creativecommons.org/licenses/by/4.0/

c) (i) Open Access

\begin{abstract}
Considerable attention has been given to oral literature in Yorùbá language. Oral literature, as regards children lullaby, children rhymes and moonlight tales are not left out. However, most of the earlier writings on folktales are centred only on the compilation of these oral literatures. However, Isola (1995) and Akinyemi (2004) have made some attempts in explaining the educational significance of these oral literatures. While Isola (1995) looks at children lullaby and children rhymes in relation to the intellectual and social development of the African child, Akinyemi's focus is on oral literature as it relates to the indigenous education for children. Our focus in this paper is on the moral value of this oral literature to both the youth and the adult. We also opine that moonlight tales, because of their moral values, should be included in the curriculum of both the primary and secondary schools. This paper, which is a deviation from the moonlight stories mentioned in Akinyemi (2004), does not look at the pranks of the tortoise but human beings. Lessons, which the stories pass across, are highlighted.
\end{abstract}

\section{Keywords}

Oral Literature, Lullaby, Rhymes, Moonlight Stories, Pranks

\section{Introduction}

Moonlight tales form part of Yorùbá culture. This is the reason why different scholars, have at one time or the other, written on the significance of this Yorùbá cultural practice (Babalola, 1970, 1973; Oyesakin, 1983; Olatunji, 1984; Adedeji, 1986; Isola, 1995; Akinyemi, 2004). Moonlight tale or folktale has a very great value in the Yorùbá environ. It is a past time practice among the Yorùbá. It is especially common during the moonlight period. Hence, there is the nomenclature "moonlight tales". The setting is always in front of the house or within a large compound. Children, because of their curiosity always form the larger number of the audience. An elderly person, whether a man or a woman, normally tells the story. Although the setting always comprises and is inclusive of family members, people from the neighbourhood also form part of the listening audience. Barber's (1991: p. 16) comments become relevant here. 
Àlọ are the most communal, domestic and democratic of Yorùbá verbal art forms. They used to be told within the compound in the evening after work with the entire household present. All were entitled to tell a tale if they wished, even the youngest; and all were expected to support the others' performances by supplying a chorus to the songs. The moral values which are the issue in these stories are correspondingly those which make for harmonious communal living. Good neighbours, loyal friends and faithful wives are contrasted with tricksters, betrayers and deceivers. The important point is not so much that the Àlọ are didactic, imparting values to the young... but that the ground and framework of every story are the values of everyday, ordinary human world. What is tested, experimented with and sometimes imaginatively abolished is the morality of communal living, based on common decency, humanity and generosity. This is the scope and the field of the discourse of Àlọ.

In telling the story, the narrator must be eloquent, versatile and must be able to carry his audience along in the story. Akinyemi (2004) buttresses this when he says:

The enjoyment of Yorùbá moonlight stories is usually attributed to the ability of the storyteller to instantly create the stories as he narrates them along... A story ends well when its inherent moral values become apparent to the audience. He must be able to tell the story in such a way that the listeners will understand the lesson inherent in it.

We discuss the paper under five sections. Section one is the introduction. Section two gives the setting of moonlight tales. In Section three, we relate some moonlight tales and their moral implications. Section four discusses the implication of moonlight tales to the educational teaching while Section five gives the conclusion.

\section{The Setting of Moonlight Tales}

Moonlight tales are in two parts. One part is precluding the other. We have Àlọ́-àpamọ (riddles) and Àlọ́-àpagbè (folktales). Àló-àpamọ comes before Àlọ́-àpagbè. Àlộ-àpamọ is normally used to awaken and to arouse the interest of the listeners and make them ready for the story proper. It is also used to awaken and to arouse the intelligence of the audience. Olatunji (1984) states five functions served by Àlọ-àpagbè.

1) They help in keeping the audience mentally awake before forktales are told.

2) They also serve as some entertainment value before the folktale is told.

3) They exercise the intellect and wit of the audience.

4) They serve as instruction in social and material culture.

5) They serve as an escape mechanism for the repressions brought about by the sanctions of the Yorùbá society.

It is pertinent to say that Àlọ-àpamọ always tasks the intellect of the audience. Most of the answers to Àlọàpamọ are always hidden in the riddle itself. For instance in

Pétẹ r’òyọọ

Pệetẹ bọ

the answer is àtẹlẹsẹ (i.e. the sole of the foot). Pẹtẹ sounds like referring to an object that looks flat. And when "àtêlẹsẹ" is considered, it looks like a flat object. Also in

Awẹ obì kan

Àjẹ r'ọyọ

àjẹ bọ

the tongue which is the answer to the riddle looks like a lobe of kolaanut. Yet another one that says

Mò ń r'ọ̀yọ

Mo kọjú s'ộyọ̣

Mò ń t’ợọ̣ bọ

Mo tún kọjú s’ọyọo o

has the talking drum as its solution. The talking drum has two "faces" and there is no way it cannot be facing the same direction whether coming or going if each side of the drum is considered as a "face". After some riddles have been given, the story teller now starts his story.

Telling moonlight tales requires some protocol. The protocol, if not followed will show the narrator as either a neophyte or a novice. Àlọ are always preceded by calling the audience into attention. The narrator does this by saying the following:

Narrator: Ààààọ 0000

Audience: àààlọ

Narattor: Àlọ mi dá fìrìgbagbó ó da lérí... 
Having said this, the narrator goes into his story. In telling the story, the story teller must be articulate, versatile and oratorical. Unlike òwe "proverb" in Yorùbá of which the giver will acknowledge the ancestors and or the elders (Abiodun, 2000), nobody credits Àl ọ to anybody; either to the forefathers or progenitor. Ogunsina (1992: p. 64) has this in mind when he says:

The Àlọ (folktales) is clearly distinct from other prose forms. Its origin is unknown as it lays no definite claim to authorship. It professes a description of actual occurrences; but in fact, it is purely imaginative, mainly intended to entertain and instruct the audience.

The narrator, in telling the story delivers it as if he were a witness to the happening he is out to narrate. He does all this in order to make his story impacting on the listeners.

The data for this paper were collected from various sources. For instance, the first three data presented below were collected orally from an elderly person while the forth one was taken from the song of Olando Owoh in one of his records. The data are presented in the English form in section three.

\section{Moonlight Stories, Its Analysis and Moral Values}

Whatever moral value the story teller desires to pass across to his audience will form the basis of the story he chooses. There are different but significant moral values embedded in each story. For instance, there are lessons on hard work as against laziness. There are those on kindness and love as against wickedness and there are those on being hospitable as against being rude to the strangers and of course, there are those on contentment as against greediness and covetousness among many others.

One other thing to be said before going into the narration of some of these stories is that some stories may be accompanied with singing in which the story teller leads and his audiences follow. When it is like this, the story teller is the one that gives the key points of the story in the song while the audiences repeat the refrain or the chorus. The song is mostly intended to give aesthetic value to the story, to awaken the audience from their slumber (since the moonlight tales are told in the night after supper) and to also drive home the point the story teller is bringing to the fore.

\subsection{Presentation of Data}

We present below, various data in form of moonlight tales to bring out the core of this paper. The method used in the data presentation is to tell the story and bring out the moral value inherent in such moonlight story.

\subsection{The Narration}

As mentioned earlier, a story may be intended to teach the audience the benefit of hard work; that whatever a person does, he will reap the reward whether sooner or later. For instance, a story that bothers on the gain of hard work is narrated thus:

Long time ago, there was a man who had two wives. The first wife was an energetic person. She was not an eye-service individual and was never used to look at anybody's face before she did her work. But the junior wife was a lazy individual. She was an indolent person. She has energy but she was not ready to work. Their husband was a farmer. The two wives had children for their husband. This husband had a very big farm where he planted yams. Eventually the yams were to be harvested. He went to the farm, harvested the yams and gathered them in a barn. He thereafter told his wives to go and carry the yams from the farm to the village. They all agreed to go. However, the second wife did not leave for the farm on time. It was after the first wife and her two children had gone and come for about three times before the second wife took off. She did not go for more than three times before she stopped and started making jest of the other wife. "I cannot kill myself, leave her let her continue to labour. If our husband wants to bring his yams from the farm, let him go and hire labourers", she started saying. All this did not deter the first wife from continuing with the work. The senior wife continued on the job until darkness fell. In the evening, the husband called the two wives and announced to them that the quantity of yams each of them had carried for the day belonged to them. On hearing this, the junior wife burst into crying and wept her heart out. But the deed had been done.

The moral lesson in this Àlo gives credence to hard work and diligence. It tells both the young and the old to 
be up and doing in what they set out to do. And that whether sooner or later, reward will come. It also brings out the fact that we should not look at others in setting a standard for ourselves. We should always be prepared to do what we believe is the right thing to do. Apart from this, the story also teaches that whatever we do will surely be rewarded. Those who labour tirelessly will receive the reward for it and those who do otherwise will also get theirs.

At times, as said earlier, moonlight tale may be narrated in such a way that song may accompany it. When songs are introduced, it serves two major purposes; one is to allow the audience to be alert. Since moonlight tales are given in the evening time, especially after the day's work and when everybody must have eaten, there may be tendency for the listeners to want to fall asleep. But when they are asked to sing the chorus of the song introduced midway in the story, whoever had already started to doze will wake up and follow the trend of the story. Secondly, it affords the listeners the opportunity to contribute to the activity; if only through the song they sing. For instance, in the story of two brothers of the same parents in which one kills the other because of money, song takes a major part in the story. The story goes thus:

Long time ago, there were two boys born to a family. After they became matured, they took to singing. After some years that they have started, they became popular. People began to call them to functions to sing and play for them. During wedding, house warming, burial ceremony, they were always called to sing. The two boys knew how to sing and dance. But the junior one knew how to sing and dance better than the senior one. They always sang and danced in a way that the onlookers always sprayed them with money. But because the junior one knew how to sing and dance better than the senior one, he always got more money than the senior one.

On day, after they have finished their play, the junior one did not want to give his money to his brother so that they could share it equally as they used to do. This did not go down well with the senior brother. After his appeal had fallen into his junior brother's deaf ears, he left it so. They started returning back to their home. On the way, the senior brother held the other one, killed him and buried him in a shallow grave beside the road. When he got home, he asked the people at home whether his brother had returned. He did this in order to cover his evil deed. The answer was negative. After they had searched for the boy to no avail, they resigned to fate.

Some months later, the mother of these boys was going along the road where her son killed by his brother was buried when she saw some mushrooms. She bent down to uproot some. Immediately she touched one of the mushrooms, they all burst into a melodious song which goes thus:

İyá má à tú o

Àjàntièlè

İyá ma à tu ò

Âjàntièlè

A roko ijó

Àjàntièlè

A jó a a yọ

Àjàntièlè

Wọn fẹgbọn líghbẹrún

Àjàntièlè

Wộn fémi lẹgbàwá

Àjàntièlè

Ló bá pa á danù

Lòsìkà ẹgbọn bá pa á danù

Àjàǹtièlè

On hearing this, the woman ran back to the village to call all other villagers to come and hear what her hear had heard. When the people got there, the scene repeated itself as the woman had narrated it to the villagers. The matter became a mystery to everybody. They then invited a herbalist, who after consulting with Ifá told them what had happened. The senior brother was then killed as instructed by the Ifá and his blood sprinkled on the mushrooms. Immediately this was done, the slain younger brother rose up from the dead.

The lesson that can be learnt from this moonlight tale is that whoever kills by the sword will also die by the sword. Not only this, it also teaches that no matter how long evil deed done in the secret lasts, perpetrator will 
eventually be caught. The important thing is that if you don't want evil to happen to you do not do evil to your neighbour. This gives credence to the Yorùbá proverb which says: Ọtafà sókè yídó borí, bọ́ba ayé kò rí o, tọrun $\dot{n}$ wò $o$. This translates to mean "if you shoot arrow to the sky and cover yourself, if nobody sees you, heaven is looking at you".

Yorùbá moonlight tales have so much to teach the womenfolk more than their men counterpart. This is why many of the Àlọ that have to do with human beings and not the pranks of the tortoise always have women as their main theme. Just as some of the Àló teach on the value of hard word, doing good and so on, so also do they teach that evil will always trail those who do evil, and that "bí a bá sòkò sọjà, ará ilé ẹni ni í bá". This means that "if one throws a stone into the market, it normally hits one's relation". The meaning of this proverb is evident in the tale given below ${ }^{1}$.

Once upon a time, there were two women who married the same husband. The husband was taking good care of them. Each of these wives had only one child for the husband. The child of each of them was a male child. These two boys born by these two different parents loved themselves so much that one would think that they were born by the same mother.

As time went on, they started going to school. The two of them were brilliant and they were making steady progress in their studies. However, the son of the junior wife appeared to be a little bit more brilliant than the son of the senior wife. For this reason, the junior wife started nursing some hatred against this son of the junior wife. She was therefore looking for a way to terminate the life of this junior wife's son. One day, she cooked a delicious food and garnished it with poison, in the hope that when the junior wife's son arrived, he would eat this food and die. She kept the food where they normally kept these children's food. Since she knew that it was this junior wife's son that normally comes home earlier than the other boy who was her own son the question of whether her own son would eat the food did not arise. But on this fateful day, it was the son of the senior wife herself that came home early. When the boy arrived, there was nobody at home; not even her mother, who could have given him the food without poison. The boy went for this delicious food, picked it and ate. As soon as he finished eating the food, he gave up the ghost. Just after the boy had died, his mother, the junior wife and the husband came in. This wicked woman knew what had happened. She knew that she had reaped, through her innocent son, the wicked fruit she sowed.

The lesson in the above tale teaches that nobody can do evil and goes away with it. The only way that evil will not befall the evil doer is not to do evil at all.

In some other Àló, the perpetrator herself could be the person that would reap the consequence of her evil deed. This is shown in another moonlight tale where two women who were married to the same husband were always at loggerhead with each other. The story is presented in the data below.

At a particular time in the past, there was a man who married two wives. He was taking care of the two of them. So his family was at peace. But these two women did not love themselves equally. The junior wife hated the senior one but she did not show the hatred openly.

One day, this jealous woman asked the hairdresser who normally plait hair for the two of them to get some hairs of the senior wife for her. The hairdresser did as this junior wife requested. But sensing danger, the hairdresser did not give her the hair of the senior wife; she gave the junior wife her own hair. After this wicked junior wife had received it, she mixed the hair with the 'juju' she had collected from a local herbalist and took it to the blacksmith's workshop. She put the hair of the senior wife under the big stone upon which the blacksmith normally hit the hot iron with an anvil. The consequence of this was that as soon as the blacksmith started to hit iron on the big stone with an anvil, the anvil would land on the senior wife's head. The blacksmith, who did not know anything started on his work. As soon as the anvil landed on the hot iron, the junior wife started to cry. Not long after this, she gave up the ghost.

The moral value in this folktale tale is that when a person does evil, nemesis will surely catch up with him/her and that the evil doer might even be the one to reap the fruit of her evil act.

\section{Educational Implication for Teaching}

Considering the foregoing, it will be observed that there are crucial lessons that could enhance the peaceful

${ }^{1}$ This story was waxed into song by the late Olandoh Owoh. Though he is not the originator of the story, we nevertheless copied the story from the song waxed by him but with some modifications. 
co-existence of people living within a community. If the lessons are imbibed, the world will be a harmonious place to live in. if this assertion is true, it is therefore imperative that folktales should be put in the curriculum of students both in the primary and secondary schools. Just as religious instructions are given to the students in schools for the purpose of inculcating the fear of God in them, so also, we believe that if folktales are part of what the pupils have to be taught in schools, it will go a long was in inculcating morals and morality in the youth. It is a known fact that all the immoral behaviours young children are known within this present age are due to lack of moral discipline. If moonlight tales are put in the curriculum of schools, these will be used in instilling moral and cultural values in our children. This fact is noted by Moser (2007: p. 3) when she says:

Traditional folktales play an important educational role in African societies. They express cultural values through metaphorical narratives and... They contain covert meanings and messages that are both amusing and thought provoking.

Yorùbá is reach in culture, and these cultures are full of moral values, some of which are got from moonlight tales. If the young children are taught these moral values in schools, all the decadence we are witnessing today among the youth of our society will be minimized if not totally eradicated.

\section{Conclusion}

It has been shown in this paper that moonlight tales are told not just for entertainment but to teach the hearers valuable lessons, which will be a better place to live in, if such lessons are imbibed and adhered to, the society, community and the world at large. We have also show that moonlight tales are relevant to the shaping and reshaping of the life of the people living within a community and even in the world at large. We have also shown, in this paper, the implication of moonlight tales to education and recommended that it should form part of the curricula in our primary and secondary schools.

\section{References}

Abiodun, M. A. (2000). Acknowledgement and the Use of Proverb in Yorùbá. Proverbium, 17, 23-26.

Adedeji, R. (1986). John West Moonlight Stories. Lagos: John West Publications Ltd.

Akinyemi, A. (2004). Yorùbá Oral Literature: A Source of Indigenous Education for Children. In K. Owolabi, \& A. Dasylva (Eds.), Forms and Function of English and Indigenous Languages in Nigeria (A Festschrift in Honour of Ayo Banjo). Ibadan: Group Publishers.

Babalola, A. (1970). Àrọ. A Minor Genre of Yorùbá Spoken Art. Paper presented at the 9th Congress of West African Linguistic Association, Freetown.

Barber, K. (1991). Multiple Discourses in Yorùbá Oral Literature. Bulletin of the John Rylands University Library of Manchester (Manchester), 73, 11-24.

Issọla, A. (1995). The Role of Literature in the Intellectual and Social Development of the African Child.

Moser, R. (2007). Kabba Folktales. LINCOM Studies in African Linguistics, 80, 3-25.

Ogunsina, B. (1992). The Development of the Yoruba Novel 1930-1975. Ibadan: Gospel Faith Mission Press.

Olatunji, O. (1984). Features of Yorùbá Oral Poetry. Ibadan: University Press Ltd.

Oyesakin, A. (1983). Categories and Functions of Yorùbá Oral Poetry for Children. Nigerian Magazine (Lagos), 51, 62-72. 
Scientific Research Publishing (SCIRP) is one of the largest Open Access journal publishers. It is currently publishing more than 200 open access, online, peer-reviewed journals covering a wide range of academic disciplines. SCIRP serves the worldwide academic communities and contributes to the progress and application of science with its publication.

Other selected journals from SCIRP are listed as below. Submit your manuscript to us via either submit@scirp.org or Online Submission Portal.
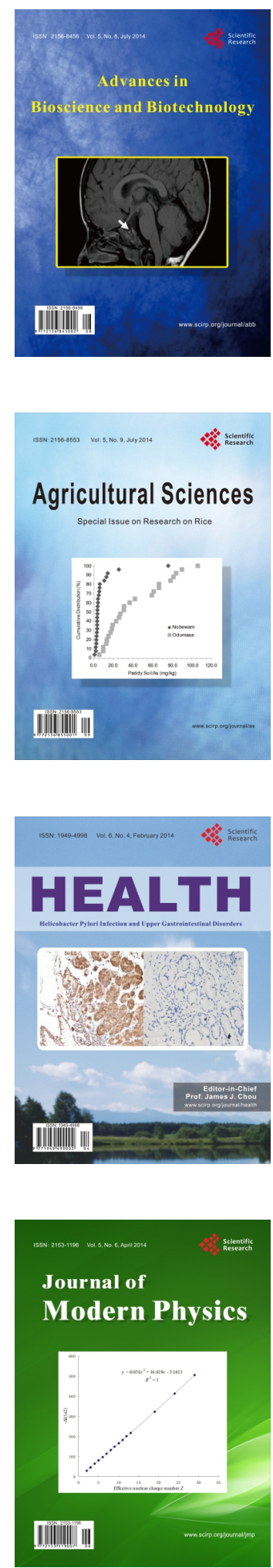
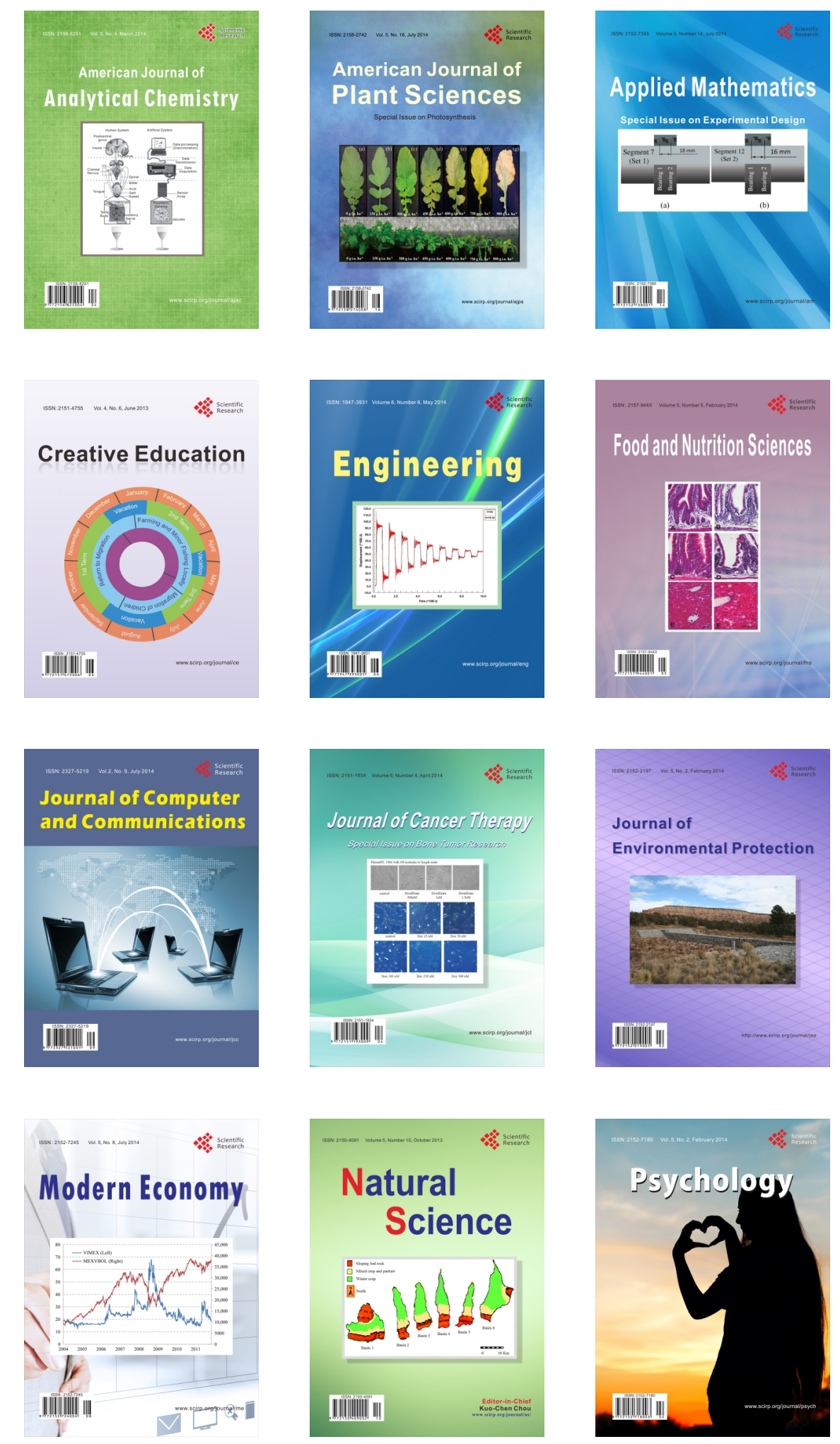